\title{
Prospective study of lymphocyte subsets in subjects genetically susceptible to Type 1 (insulin-dependent) diabetes
}

\author{
P. Pozzilli1 ${ }^{1,3}$, M. Sensi ${ }^{3}$, L.Al-Sakkaf ${ }^{4}$, A. Tarn ${ }^{1}$, O.Zuccarini ${ }^{3}$ and G. F. Bottazzo ${ }^{2}$ \\ ${ }^{1}$ Department of Diabetes and Immunogenetics, St. Bartholomew's Hospital, ${ }^{2}$ Department of Immunology, Middlesex Hospital, London, UK, \\ ${ }^{3}$ Cattedra di Endocrinologia (I), University of Rome, Italy and ${ }^{4}$ Department of Microbiology, Faculty of Medicine, University of Kuwait, \\ Kuwait
}

\begin{abstract}
Summary. A prospective study of lymphocyte subsets has been carried out for 18 months in 58 healthy first-degree relatives of Type 1 (insulin-dependent) probands. Subjects selected for presence or absence of islet cell antibodies included 10 with complement-fixing islet cell antibodies, 10 with conventional islet cell antibodies and 38 without islet cell antibodies. Immunoregulatory and effector lymphocyte subsets, and in particular activated T-cells, were investigated using a panel of monoclonal antibodies. The results showed no significant changes in total $\mathrm{T}$, helper, suppressor/cytotoxic cells or $\mathrm{K}$ / NK cells. Activated T-cells were observed at least once in 22 subjects using the $4 \mathrm{~F} 2$ monoclonal antibody and in 11 using the Tac antibody. Seven subjects had 4F2-positive cells on repeated occasions and one twice showed Tac-positive cells. Fluctuations and/or loss of islet cell antibodies were observed
\end{abstract}

during follow-up. There was no correlation between presence of activated T-cells and either islet cell antibody status or HLA haplotype sharing with the diabetic proband. On the other hand, a significant correlation was observed between HLA-DR3 positivity of subjects and the occurrence of activated T-cells (both 4F2-positive and Tac-positive). We conclude that subjects with HLA-DR3 may be especially prone to T-cell activation. As none of the 'high risk' individuals developed diabetes in the course of follow-up, the relevance of these observations in the pathogenesis of Type 1 diabetes needs more prolonged investigation.

Key words: Type 1 diabetes, pre-diabetic state, genetic susceptibility, lymphocyte subpopulations, activated T-cells.
It is now well recognized that abnormalities in lymphocyte subpopulations are present in patients with newly diagnosed Type 1 diabetes. Alterations in the peripheral blood include the presence of activated DR-positive Tcells [1,2], the decrease of suppressor cell number and function $[3,4]$ and an increased number and function of killer cells $[5,6]$.

It is still unclear what is the meaning of such abnormalities and whether they are primarily involved in the pathogenesis of the disease or are merely a secondary phenomenon present at the time of onset. One possible approach to this question is a prospective study in genetically and immunologically susceptible, but otherwise normal, first-degree relatives of Type 1 diabetic probands.

The Barts-Windsor-Middlesex Family Study, which was started in 1978, has clearly indicated, by regular testing of unaffected relatives of diabetic children, that humoral autoimmune phenomena may exist for years in some of those who have inherited the "diabetogenic genes' [7, 8]. In order to investigate the role of cell-mediated immune phenomena in the prediabetic period, a prospective study of lymphocyte subsets was started in 1982 by selecting a group of first-degree relatives in our family study.

The aim of this study was to define whether abnormalities of the immunoregulatory/effector cell subsets can occur in individuals susceptible to Type 1 diabetes, and whether such changes are persistent and can be regarded as markers for an ongoing autoimmune process directed against the $\beta$ cells.

\section{Subjects and methods}

\section{Subjects}

Fifty-eight first-degree relatives of Type 1 diabetic probands entered the study. They were selected as follows: group A: 10 subjects (eight siblings and two parents) whose sera showed complement-fixing islet cell (CF-ICA) on at least one occasion; group B: 10 subjects (six siblings and four parents) who had conventional ICA (ICA-IgG) on one or more occasions; group C: 38 subjects (17 siblings and 21 parents) who, repeatedly tested for 3 years, were always negative for ICA-IgG and CF-ICA. 
(A)

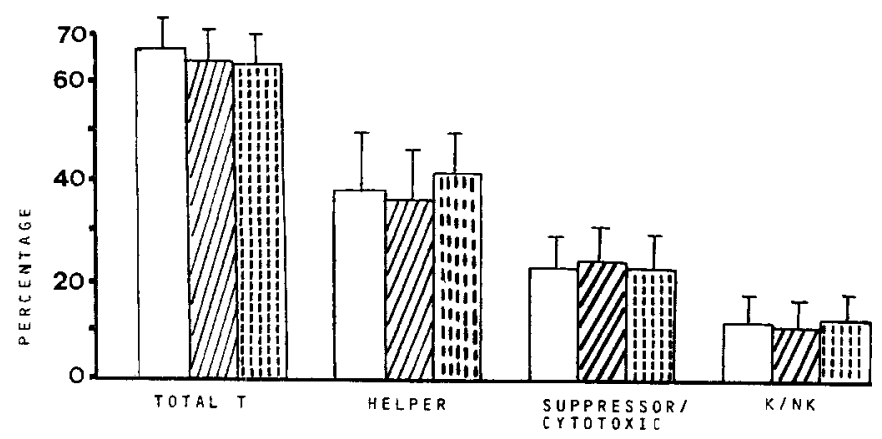

(B)
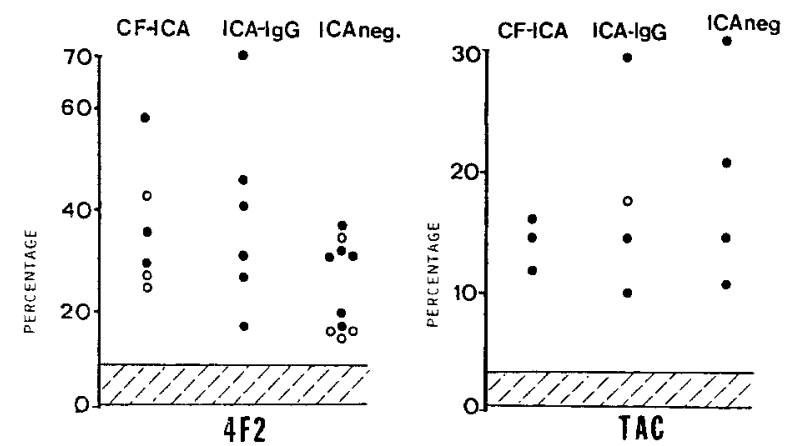

Fig. 1. A The lymphocyte subsets (expressed as percentage of total mononuclear cells) in the 18-month-prospective study in the three groups of subjects. $\square$ : CF-ICA; שICA-IgG; سICA-negative (ICAneg) Differences between groups are not significant. B The proportions of activated T-cells (4F2-positive and Tac-positive; expressed as percentage of total mononuclear cells) in the three groups of subjects. Only specimens with percentages $>2 S D$ above the normal mean (shaded area) are represented. $0=$ the mean values of activated $\mathrm{T}$ cells in subjects who repeatedly showed these cells in the peripheral blood

All subjects were HLA-A, -B, -C and -DR typed [9]; nine siblings did not share HLA haplotypes with the diabetic probands (two in group B and seven in group C).

The blood glucose levels were within the normal range in all subjects at the time of entry into the study.

\section{Lymphocytes}

Blood peripheral mononuclear cells were collected approximately every 4-5 months over a period of 18 months. Cells were obtained by centrifugation of venous blood on Lymphoprep (Nygaard, Oslo, Norway), washed twice in Hank's balanced salt solution before being phenotyped.

\section{Procedures}

Cells $\left(3.0 \times 10^{5} /\right.$ tube) were incubated for $30 \mathrm{~min}$ at $4{ }^{\circ} \mathrm{C}$ separately with $50 \mu \mathrm{l}$ of the appropriate dilution of each of the following monoclonal antibodies: UCHT1 [10], for total T-cells; UCHT4 [11] for suppressor/cytotoxic T-cells (analogous to OKT8 or Leu 2a); Leu 3 a for helper cells (Becton Dickinson, Sunnyvale, California, USA); H25 [12] for $\mathrm{K} / \mathrm{NK}$ cells; 4F2 [13] for activated $\mathrm{T}$ cells; anti-Tac [14] for activated T-cells (receptor for the T-cell growth factor).

After incubation, cells were washed twice in Hank's solution and incubated with fluorescein-conjugated rabbit anti-mouse antiserum for $30 \mathrm{~min}$ at $4{ }^{\circ} \mathrm{C}$. Cells were then washed again twice in Hank's solution and for each of the monoclonal antibodies tested the percentage
Table 1. Relationship between presence of activated T-cells and lymphocyte subsets

\begin{tabular}{|c|c|c|c|c|}
\hline \multirow[t]{2}{*}{$\begin{array}{l}\text { Specimens groups } \\
\text { by presence of } \\
\text { activated T-cells }\end{array}$} & \multirow[b]{2}{*}{$\begin{array}{l}\text { Number of } \\
\text { specimens }\end{array}$} & \multicolumn{3}{|c|}{$\begin{array}{l}\text { Lymphocyte subsets as } \\
\text { proportion of mononuclear } \\
\text { cells }\end{array}$} \\
\hline & & $\begin{array}{l}\text { Total } \\
\text { T-cells } \\
(\%)\end{array}$ & $\begin{array}{l}\text { Helper/ } \\
\text { suppressor } \\
\text { ratio }(\%)\end{array}$ & $\begin{array}{l}\mathrm{K} / \mathrm{NK} \\
(\%)\end{array}$ \\
\hline \multicolumn{5}{|l|}{$\begin{array}{l}\text { Activated T-cells } \\
\text { present by the } \\
\text { following criteria: }\end{array}$} \\
\hline $\begin{array}{l}>15 \% \text { of cells } 4 \mathrm{~F} 2- \\
\text { positive }^{\mathrm{a}}\end{array}$ & 22 & $62 \pm 16$ & $1.4 \pm 0.5^{\mathrm{b}}$ & $16 \pm 10$ \\
\hline $\begin{array}{l}>10 \% \text { of cells Tac- } \\
\text { positive }^{\mathrm{a}}\end{array}$ & 11 & $52 \pm 16$ & $1.5 \pm 0.9^{b}$ & $25 \pm 13^{\mathrm{c}}$ \\
\hline $\begin{array}{l}\text { Activated T-cells } \\
\text { absent by both } \\
\text { tests }\end{array}$ & 129 & $63 \pm 7$ & $1.8 \pm 0.6$ & $9 \pm 8$ \\
\hline
\end{tabular}

of cells positive for rim fluorescence was determined using a Leitz inverted fluorescence microscope (Leitz, Wetzlar, FRG) and a Hamax plate (Medicell International, London, UK), which allows the use of very low cell concentration [15].

Islet cell antibodies (ICA-IgG and CF-ICA) were measured on sections of human pancreas (group 0 ) as described previously [16].

\section{Results}

Minimal variations of immunoregulatory/effector cell subpopulations (helper, suppressor/cytotoxic, K/NK) were observed over the follow-up period in the three groups of subjects studied (Fig. 1). Activated T-cells as evaluated by the anti-Tac and 4F2 antibody are also shown in Figure 1. Only 11 subjects (five parents and six siblings - one on two occasions) showed Tac-positive cells; 22 subjects ( 10 parents and 12 siblings - seven on two occasions) had 4F2-positive cells. When Tac-positive cells were present, 4F2-positive cells were not detectable. However, four subjects with Tac-positive cells had shown 4F2-positive cells on previous occasions.

Activated T-cells (either 4F2-positive or Tac-positive) appear equally distributed in the three groups of subjects (Fig. 1).

During the 18 months of follow-up, CF-ICA and ICA-IgG fluctuated in both group A and group B; however, CF-ICA and ICA-IgG did not appear in group C during follow-up. Also, taking into consideration the fluctuations of ICA, there was no correlation between presence of activated T-cells and ICA. Thus only two out of 11 subjects with Tac-positive cells and six out of 22 subjects with 4F2-positive cells were positive for $\mathrm{CF}$ ICA and/or ICA-IgG in the same blood sample. 
Table 2. Relationship between activated T-cells and the HLA-DR phenotype

\begin{tabular}{llllll}
\hline HLA & $4 \mathrm{~F}^{\mathrm{a}}$ & & \multicolumn{2}{l}{ Tac $^{\mathrm{a}}$} \\
\cline { 2 - 3 } & $>15 \%$ & & & $>15 \%$ & $<10 \%$ \\
\hline DR3 & 14 & 11 & & 9 & 16 \\
DRX $^{\mathrm{b}}$ & 8 & 25 & & 2 & 31 \\
& \multicolumn{2}{c}{$p<0.05^{\mathrm{c}}$} & & \multicolumn{2}{c}{$p<0.02^{\mathrm{c}}$} \\
\hline
\end{tabular}

${ }^{\text {a }} 4 \mathrm{~F} 2>15 \%$ and $\mathrm{Tac}>10 \%$ represent values $2 \mathrm{SD}$ above the normal mean. Figures represent numbers of subjects in each group who were positive for activated T-cells on at least one occasion (on left), or negative on every occasion (on right); ${ }^{\mathrm{b}} \mathrm{DRX}=$ any $\mathrm{DR}$ allotype except DR3; ${ }^{c} \chi^{2}$ test (with Yates' correction)

The relationship between the presence of activated T-cells and other lymphocyte subsets is shown in Table 1 . When activated T-cells are present, abnormalities of lymphocyte subpopulations are observed, including a decreased helper/suppressor-cytotoxic ratio and increased percentage of $\mathrm{K} / \mathrm{NK}$ cells.

Finally, no correlation was observed between the sharing of HLA haplotype with the diabetic proband and activated $T$ cells, whereas a significant correlation was found between HLA-DR3-positive subjects and the occurrence of activated T-cells (4F2 and Tac) (Table 2).

None of the subjects studied developed diabetes during the follow-up period.

\section{Discussion}

This 18-month prospective study of lymphocyte subsets in first-degree relatives of Type 1 diabetic probands has demonstrated minimal variations in subpopulations of the immunoregulatory/effector cells, whereas activated $\mathrm{T}$ cells were observed in some individuals. The main finding is that HLA-DR3 positive individuals may be more prone to $\mathrm{T}$-cell activation. This observation may be relevant in the wide spectrum of autoimmune diseases characterized by an association with HLA-DR3 and activated T cells (i. e. Graves' disease, Type 1 diabetes, myathenia gravis) [17]. It has been suggested that either a gene associated with HLA-DR3 may predispose to autoimmunity [18] or, as the autoantigens involved in the various HLA-DR3 associated diseases are different, the preponderance of HLA-DR3 may reflect a relative ease of induction of aberrant DR in epithelial cells of individuals expressing these antigens [19]. The possibility that HLA-DR3 strongly influences the cell-mediated immune response is also suggested by data showing increased number of plaque-forming cells in culture from HLA-DR3 subjects [20]. Therefore our observation of a significant correlation between DR3 and activated T cells support this concept.

However, since none of the "high risk" individuals has developed diabetes in the past 3 years, the relevance of these observations in the pathogenesis of Type 1 diabetes needs more prolonged investigation of these sub- jects. The fact that ICA may become undetectable in genetically predisposed subjects [21] fits well with the present observation that presence of activated $T$ cells can also fluctuate, suggesting that susceptible individuals do possess natural protective mechanisms against autoimmune damage such as enhanced suppressor Tcell function or anti-idiotype response to ICA or to autoreactive $T$ cells [22]. In this context, it is of interest that when activated $T$ cells were found, the helper/suppressor ratio was strongly reduced due in particular to a reduction of cells carrying the suppressor/cytotoxic phenotype.

In conclusion, future efforts must concentrate on the identification of both the crucial destructive mechanisms and the potentially important regenerative processes which may counteract $\beta$-cell destruction.

Acknowledgements. This work was supported by grants from the Juvenile Diabetes Foundation, the British Diabetic Association, the Joint Research Board of St. Bartholomew's Hospital and the Fondazione Cenci Bolognetti Istituto Pasteur. We are indebted to Dr. W. A. Waldmann, National Institutes of Health, Bethesda, for the gift of anti-Tac monoclonal antibody; Dr. G. S. Eisenbarth, The Joslin Clinic, Boston, for the 4F2 antibody; to Dr. P.C.L. Beverley, ICRF University College Hospital, London, for the $\mathrm{H} 25$ antibody. We are also grateful to S. Morris, The Computer Centre, St. Bartholomew's Hospital, London, for the statistical analysis of the data.

\section{References}

1. Jackson RA, Morris MA, Haynes BF, Eisenbarth GS (1982) Increased circulating Ia bearing $T$ cells in Type 1 diabetes mellitus. N Engl J Med 306: 785-788

2. Pozzilli P, Zuccarini O, Iavicoli M, Andreani D, Spencer KM, Bottazzo GF, Beverley PCL, Kyner JL, Cudworth AG (1983) Monoclonal antibodies defined abnormalities of $\mathrm{T}$ lymphocytes in Type 1 diabetes. Diabetes 32: 91-94

3. Buschard K, Madsbad S, Rygaard J (1980) Depressed suppressor cell activity in patients with newly diagnosed insulin dependent diabetes mellitus. Clin Exp Immunol 45: 25-31

4. Fairchild RS, Kyner JL, Abdou NI (1982) Specific immunoregulation abnormality in insulin dependent diabetes mellitus. J Lab Clin Med 99: 175-186

5. Pozzilli P, Sensi M, Gorsuch AN, Bottazzo GF, Cudworth AG (1979) Evidence for raised $\mathrm{K}$ cell levels in Type 1 diabetes. Lancet 2: $173-175$

6. Sensi M, Pozzilli P, Gorsuch AN, Bottazzo GF, Cudworth AG (1981) Increased killer cell activity in Type 1 diabetes. Diabetologia 20: 106-109

7. Bottazzo GF, Pozzilli P, Mirakian R, Dean BM, Doniach D (1984) Early immunological events in diabetes. In: Andreani D, Di Mario U, Federlin KF, Heding LG (eds) Immunology in diabetes. Kimptom Medical Publications, London, pp 95-104

8. Cudworth AG, Wolf E (1982) The genetic susceptibility to Type 1 diabetes. Clin Endocrinol Metab 11:389-406

9. Wolf E, Spencer KM, Cudworth AG (1983) The genetic susceptibility to Type 1 (insulin-dependent) diabetes: analysis of the HLADR association. Diabetologia 24: 224-230

10. Beverley PCL, Callard RE (1981) Distinctive functional characteristics of lymphocytes defined by E-rosetting or a monoclonal antibody anti-T cell antibody. Eur J Immunol 11: 329-334

11. Beverley PCL (1982) The application of monoclonal antibodies to the study of lymphoreticular cells. Proc Roy Soc Edinburgh 13: $521-527$ 
12. Bay Y, Callard RE, Beverley PCL, Bodmer WF (1983) Two monoclonal antibodies (H25 and H366) defined cells with $\mathrm{K} / \mathrm{NK}$ activity. Eur J Immunol 48: 189-195

13. Haynes BF, Hemler ME, Mann DL, Eisenbarth GS, Shelhamer JH, Mostowski HS, Thomas CA, Strominger JL, Fauci AS (1980) Characterisation of a monoclonal antibody (4F2) which binds to human monocytes and to a subset of activated lymphocytes. J Immunol 126: 1409-1411

14. Leonard JJM, Depper T, Uchiyama T, Smith KA, Waldmann TA, Greene C (1982) A monoclonal antibody that appears to recognize the receptor for human $T$ cell growth factor: partial characterization of the receptor. Nature (Lond) 300:267-269

15. Sensi M, Pozzilli P, Di Mario U (1984) A method to facilitate the reading of up to 60 samples of monoclonal antibody-fluorescence stained cells using Medicell HLA-DR plates. J Clin Lab Immunol 13: 101-102

16. Bottazzo GF, Dean BM, Gorsuch AN, Cudworth AG, Doniach D (1980) Complement fixing islet cell antibodies in Type 1 diabetes: possible monitors of active beta cell damage. Lancet 1: 668-672

17. Bodmer WF (1980) The HLA system and disease. J Roy Coll Physicians $14: 43-50$
18. Bodmer WF (1981) MHC gene clusters of man and mouse. In: Russell E (ed) Mammalian genetics and cancer, Alan Liss, New York, pp 213-240

19. Bottazzo GF, Pujol Borrell R, Hanafusa T (1983) Role of aberrant HLA-DR expression and antigen presentation in induction of endocrine autoimmunity. Lancet 2: 1115-1118

20. Lawley TJR, Hall A, Fauci AS, Katz SI, Hamburger MI, Frank MM (1981) Defective Fc receptor functions associated with the HLA-B8/DRW3 haplotype. N Engl J Med 304: 185-187

21. Spencer KM, Tarn A, Dean BM, Lister J, Bottazzo GF (1984) Family studies in Type 1 diabetes: evidence of fluctuating islet cell autoimmunity in unaffected relatives. Lancet 1: 764-765

22. Lamb JR, Feldmann M (1982) A human suppressor T cell clone which recognizes an autologous helper T cell clone. Nature 300: $456-458$

Dr. P. Pozzilli

Department of Diabetes and Immunogenetics

St. Bartholomew's Hospital

London EC1A 7BE

UK 